\title{
Are Elevated Levels of IGF-1 Caused by Coronary Arteriesoclerosis?: Molecular and Clinical Analysis
}

\author{
Pawel Burchardt • Anna Gozdzicka-Jozefiak • \\ Jakub Zurawski · Witold Nowak · Julia Durzynska • \\ Rafał Link · Tomasz Grotowski · Tomasz Siminiak
}

Published online: 4 November 2010

(c) The Author(s) 2010. This article is published with open access at Springerlink.com

\begin{abstract}
The importance of insulin-like growth factor-1 (IGF-1) in coronary artery disease (CAD) due to wide range of its biological effects and its therapeutic potential, has already been described. Our aim was to evaluate possible influence of IGF-1 serum level changes on coronary atherosclerosis. In case of existence of such association our further aim was to verify and explain this phenomenon by examination of promoter P1 of IGF-1gene and receptor gene for IGF-1. The study was performed in 101 consecutive patients undergo for routine coronary angiography. Quantitative and qualitative assessment of coronary atherosclerosis was performed respectively by estimation of the number of culprit lesions in coronary arteries and by Gensini score calculation. IGF-1, IGFBP3 and plasma lipoproteins were measured in all patients. In addition, we evaluated DNA from 101 patients, isolated from blood cells, which was amplified by using PCR with sophisticated
\end{abstract}

\section{P. Burchardt $(\square)$}

Division of Cardiology-Intensive Therapy, Department

of Internal Medicine, Poznan University of Medical Sciences, ul. Przybyszewskiego 49, 60-355 Poznan, Poland

e-mail: pab2@tlen.pl

A. Gozdzicka-Jozefiak · W. Nowak · J. Durzynska

Department of Biology, Adam Mickiewicz University, Poznan, Poland

\section{J. Zurawski}

Department of Biology and Environmental Sciences, Poznan

University of Medical Sciences, Poznan, Poland

R. Link · T. Grotowski

Kowanowko Cardiac and Rehabilitation Hospital, Kowanowko, Poland

T. Siminiak

Poznan University of Medical Sciences, Poznań, Poland primers for P1 promoter of IGF-1 gene and IGF-1 receptor gene, then analyzed utilizing SSCP technique and automatically sequenced. We observed significant increase of serum IGF-1 levels in patients with "3 vessel disease" and with high score in Gensini scale when compared to those without any narrowing lesions in coronary arteries and 0 Gensini score (in group with 3 vessel disease $215.0 \pm 71.3$ versuss $176.7 \pm 34.2 \mathrm{ng} / \mathrm{ml} \quad p=0.04$ and with high Gensini score $231.4 \pm 59.3$ versus $181.0 \pm 37.8 \mathrm{ng} / \mathrm{ml}$ $p=0.01)$.We found different genotypes for five P1 promoter polymorphisms of IGF-1 gene (RS35767, RS57426 12, RS228837, RS11829693, RS17879774). There were no significant associations between the observed single nucleotide polymorphism (SNP) and coronary atherosclerosis nor with levels of circulating IGF-1. We found no structural polymorphism in receptor gene for IGF-1 nor in its extracellular domain(exon 2-4) nor in internal domain (exon 16-21). The effect of increased IGF-1 serum level in our study was probably independent from structural polymorphism in promoter P1 for IGF-1 or in receptor gene for IGF-1.

Keywords IGF-1 - Promoter P1 polymorphism - Growth hormones $\cdot \mathrm{CAD}$

$\begin{array}{ll}\text { Abbreviations } \\ \text { Apo A1 } & \text { Apoprotein A1 } \\ \text { Apo B100 } & \text { Apoprotein B-100 } \\ \text { BMI } & \text { Body mass index } \\ \text { CAD } & \text { Coronary artery disease } \\ \text { DM } & \text { Diabetes mellitus } \\ \text { GH } & \text { Growth hormone } \\ \text { HDL,LDL } & \text { High/low density lipoproteins } \\ \text { IGF } & \text { Insulin like growth factor }\end{array}$




$\begin{array}{ll}\text { Lp(a) } & \text { Lipoprotein a } \\ \text { MI } & \begin{array}{l}\text { Myocardial infarction } \\ \text { Nt }\end{array} \\ \text { NYHA } & \begin{array}{l}\text { New Yootide } \\ \text { classification of advancing of heart failure }\end{array} \\ \text { QCA } & \text { Quantitative coronary angiography } \\ \text { SSCP } & \text { Single strand conformational polymorphism } \\ \text { TC } & \text { Total cholesterol }\end{array}$

\section{Introduction}

IGF-1 is a product of IGF-1 gene, which is mapped on 12 chromosome [6]. There are two transcription start sites located on exon 1 and 2, what results in two different carboxyl-terminal domains of IGF (Ea and $\mathrm{Eb}$ ). Eb transcripts are mainly expressed in the liver. Besides this, IGF1 is also synthetised in kidneys, kardiomyocytes, VSMC's, fibroblasts etc., as a result of (growth hormone) GH-GH receptor interaction [6].

The importance of insulin-like growth factor-1 (IGF-1) in coronary artery disease (CAD) due to a wide range of its biological effects and its therapeutic potential has already been discussed in literature $[1,6,8]$.

A potential proinflammatory effect of IGF-1 was explored by Che (2002) who suggested that IGF-1 enhanced TNF- $\alpha$-dependent adhesion molecule expression in cultured bovine VSMC's [5]. Grant et al. (1996) [9] was the first publication to report lack of IGF-1 expression in normal coronary arteries and its overexpresion in postatherectomy specimens. Okura et al. (2001) and Patel et al. (2001) [13, 14] described reduction of local IGF-1, IGFR in advanced plaque, possibly due to proinflammatory cytokines, and ox-LDL effect. Reduced IGF-1 expression and low IGF-1 bioavailability triggered by high level of IGFBP4 could be responsible for ox-LDL- induced cytotoxity and apoptosis in VSMCs. This process could in turn facilitate plaque instability or rupture [15]. Jansen (1998) [10] associated high serum IGF-1 levels with decreased prevalence of CAD.

IGF-1 synthesis is controlled and regulated by various mechanisms and enzymes. Any of those mechanisms may contribute to changes in phenotype protein levels [2]. The efficacy of that process may depend on structure of: IGF-I gene, gene regulatory sequences or receptor gene for IGF1. Our aim was to evaluate possible influence of IGF-1 serum level changes on coronary atherosclerosis. In case of existence of such association our further aim was to verify and explain this phenomenon by examination of promoter P1 of IGF-1gene and receptor gene for IGF-1. According to the fact of constitutive properties of IGF-1 gene we did not decide to analyze its sequence.

\section{Materials and Methods}

Blood samples were collected from 101 consecutive patients undergoing routine coronary angiography, at 8.00 AM before catherization, to avoid the effect of dailydependence of IGF-1 release rhythm.

\subsection{Determination of IGFPB3, IGF-1, Lipoprotein Levels}

IGF-1 serum levels were measured by radio immune assay technique with the use of commercial kits from Biosource (Nivelles, Belgium).

The lipid levels were measured using enzymatic kits and the Architect system (Abbott, San Diego, California).

\subsection{Detection of Polymorphisms by SSCP and by Sequencing}

The isolation of genomic DNA with salt-extraction approach was used as described in [3] and [4]. Subsequently, the purity of obtained DNA was assessed with electrophoresis on $0.8 \%$ agarose gel.

Using polymerase chain reaction (PCR) analyses of sequences of the P1 promoter (divided into 4 fragments: region a between -1404 to $-1134 \mathrm{nt}$, region $\mathrm{b}$ between -1115 to $-784 \mathrm{nt}$, region c between -633 to $-305 \mathrm{nt}$, and region d between -250 to $+49 \mathrm{nt}$ ) of IGF-1 gene as well as for IGF-1 receptor gene (exons 2-4 and 16-21) were performed for each patient. PCR primers were selected from IGF-1 gene promoter sequences and IGF-1 receptor gene sequences taken from the Entrez Gene database. The products of DNA amplification were verified with electrophoresis on $2 \%$ agarose gel and analyzed using single strand conformation polymorphism (SSCP) to evaluate IGF-1 gene $\mathrm{P} 1$ promoter polymorphism or IGF-1 receptor gene polimorphism. DNA fragments were separated by electrophoresis and underwent further silver staining. Beckman-Coulter Genetic Analysis System CEQ 2000XL with capillary electrophoresis technology and fluorescence detection option was used for automated sequencing, allowing for a more accurate determination of nucleotide sequence changes essential for the identification of the IGF-1 gene promoter P1 or IGF-1 receptor gene structure.

TRANSFAC system was additionally employed to find transcriptional factors which may hypothetically become attached to the observed P1 promoter sequence.

\subsection{Coronary Images Analysis}

The coronarography images were analyzed by quantitative coronary angiography (QCA) technique and the Gensini score was calculated for quantification of arteriosclerotic changes. 
Gensini score is calculated by assigning to every (even an insignificant one) atherosclerotic lesion a suitable quantity of points, depending on the vessel priority. In such cases, a 30\% narrowing lesion is given more points in proximal left descending artery than in proximal left circumflex artery.

\subsection{Patient Selection}

Inclusion criteria for patients was included "positive" result of ECG exercise test, what was established no longer then 4 weeks before catherization. Patients were excluded if they displayed acute coronary syndrome, myocardial infarction (MI) during the preceding 3 months, acute congestive heart failure (NYHA III/IV), acute or chronic hematopoietic disease, cancer, acromegaly, or inflammation originating from bacterial, viral, or fungal infections. The study protocol was approved by the local ethics committee [4].

\subsection{Statistics}

Normality was tested in Shapiro-Wilk's W test. At normal variables of distribution we used $T$-Student test (for two independent variables) or Levene test and analysis of variances (for multiple independent samples). MannWhitney test (for two independent variables) and KruskalWallece (for multiple independent samples) test were used at abnormal variables of distribution. We also used crosstabulation tables with one and two tailed Fisher exact, and $\chi 2$ Person's tests. Additionally, we employed Spearman's rang correlations and the correlation coefficient (at normal variable distribution). Statistical analysis was conducted using STATISTICA 7.0 software. The results are given as mean \pm SD.

Table 1 Characteristics of the studied group
apoA1 Apoprotein $\mathrm{A} 1$, apoB apoprotein B-100, BMI body mass index, $H D L, L D L$ lipoproteins, $I G F$ insulin like growth factor, $\operatorname{Lp}(a)$ lipoprotein a, $T C$ total cholesterol, $T G$ triglycerides

$* p<0.05$

apoA1 Apoprotein A1, apoB
apoprotein B-100, $B M I$ body
mass index, $H D L, L D L$
lipoproteins, $I G F$ insulin like
growth factor, $L p(a)$ lipoprotein
a, $T C$ total cholesterol, $T G$
triglycerides
$* p<0.05$

The protocol of the study was accepted by a local committee on human research. Every patient was individually informed and received study consent form to sign.

\section{Results}

Characteristics of studied group. 101 consecutive patients (44 women and 57 men) undergoing coronarography were involved. The average age was $59.2 \pm 10.2$ years for men and $61.1 \pm 10.03$ years for women. Significant lesions (above $50 \%$ of the vessel lumen) in one coronary artery were observed in 22 subjects ( 17 Men and 5 Women), in two arteries in 15 patients $(11 \mathrm{M}, 4 \mathrm{~W})$, whereas the three vessel disease was diagnosed in 22 patients $(12 \mathrm{M}, 10 \mathrm{~W})$. No significant changes (less than 30\%) in coronary arteries were found in 32 patients and a group of 10 patients had arteriosclerotic changes between 30 and 50\% of artery lumen. 38 patients ( $24 \mathrm{M}, 14 \mathrm{~W}$ ) had history of myocardial infarction (MI), 36 patients $(20 \mathrm{M}, 16 \mathrm{~W})$ had family history of CAD, history of stroke was positive in 5 patients. Basic clinical parameters are shown in Table 1, 2, 3 .

Results of biochemical analysis. Average IGF-1 levels were $197.5 \pm 57.1 \mathrm{ng} / \mathrm{ml}$, and IGFBP3 levels were $2102.7 \pm 649.74 \mathrm{ng} / \mathrm{ml}$, whereas mean lipid values for the groups studied were: total cholesterol (TC) $194.6 \pm$ $51.0 \mathrm{mg} / \mathrm{ml}$, HDL $48.7 \pm 15.3 \mathrm{mg} / \mathrm{ml}$, low density lipoprotein (LDL) $118.1 \pm 44.4 \mathrm{mg} / \mathrm{ml}$, triglycerides (TG) $144.2 \pm 71.5 \mathrm{mg} / \mathrm{ml}$. We observed significant increase of serum IGF-1 levels in patients with "3 vessel disease" and with high score in Gensini scale when compared to those without any narrowing lesions in coronary arteries and 0 Gensini score (in group with 3 vessel disease $215.0 \pm 71.3$ versuss $176.7 \pm 34.2 \mathrm{ng} / \mathrm{ml} p=0.04$ and with high Gensini

\begin{tabular}{llll}
\hline & $\begin{array}{l}\text { Mean value } \\
\pm \text { SD in female group } \\
(\mathrm{N} \mathrm{44})\end{array}$ & $\begin{array}{l}\text { Mean value } \\
\pm \text { SD in male group } \\
(\mathrm{N} \mathrm{57)}\end{array}$ & $\begin{array}{l}\text { Mean value } \\
\pm \text { SD in studied group } \\
(\mathrm{N} \mathrm{101)})\end{array}$ \\
\hline Weight $(\mathrm{kg})$ & $\begin{array}{l}72.7 \pm 14.0 \\
\text { Height }(\mathrm{cm})\end{array}$ & $82.8 \pm 13.83$ & $78.47 \pm 14.7$ \\
BMI & $159.2 \pm 6.92$ & $171.57 \pm 6.67$ & $166.3 \pm 9.12$ \\
Hypertension \% & $28.57 \pm 4.52$ & $28.07 \pm 4.05$ & $28.28 \pm 4.24$ \\
Diabetes mellitus\% & 28.6 & 62 & 69 \\
Smokers\%* & 11.9 & 21 & 24.5 \\
TC mg/ml & $198.7 \pm 55.14$ & 30 & 22.4 \\
HDL $\mathrm{mg} / \mathrm{ml}$ & $53.31 \pm 16.32$ & $191.46 \pm 47.88$ & $194.6 \pm 50.97$ \\
LDL $\mathrm{mg} / \mathrm{ml}$ & $116.59 \pm 48.3$ & $45.21 \pm 13.58$ & $48.68 \pm 15.28$ \\
TG $\mathrm{mg} / \mathrm{ml}$ & $144.26 \pm 59,12$ & $119.21 \pm 41.65$ & $118.1 \pm 44.37$ \\
IGF-1/BMI kg/m^2 & $6.571 \pm 1.912$ & $144.21 \pm 79.99$ & $144.2 \pm 71.46$ \\
IGF-1 ng/ml & $183.71 \pm 47.25$ & $207.91 \pm 61.88$ & $7.147 \pm 2.35$ \\
IGFBP3 ng/ml & $2210.9 \pm 675,9$ & $2021.6 \pm 623.13$ & $197.5 \pm 57.1$ \\
\hline
\end{tabular}


Table 2 Characteristics of groups due to arteriosclerosis
apoA1 Apoprotein $\mathrm{A} 1$, apoB apoprotein B-100, $B M I$ body mass index, $H D L, L D L$

lipoproteins, $I G F$ insulin like growth factor, $L p(a)$ lipoprotein a, $T C$ total cholesterol, $T G$ triglycerides

${ }^{*} p<0.05$

Table 3 Characteristics of groups due to arteriosclerosis
apoA1 apoprotein $\mathrm{A} 1, a p o B$ apoprotein B-100, BMI body mass index, $H D L, L D L$

lipoproteins, $I G F$ insulin like growth factor, $\operatorname{Lp}(a)$ lipoprotein a, $T C$ total cholesterol, $T G$ triglycerides

$* p<0.05$

\begin{tabular}{lll}
\hline & $\begin{array}{l}\text { Coronary arteries without } \\
\text { narrowing lesions in } \\
\text { coronarography, negative history } \\
\text { of MI, negative familial CAD history, } \\
\text { 0 points in Gensini scale mean } \\
\text { value } \pm \text { SD (N 11) }\end{array}$ & $\begin{array}{l}\text { Significant lesions } \\
\text { in all coronary arteries/ } \\
\text { three vessels disease/, } \\
\text { mean value } \pm \text { SD (N 20) }\end{array}$ \\
& $56.3 \pm 9.0$ & \\
\hline Age [years]* & $78.8 \pm 16.5$ & $64.5 \pm 9.1$ \\
Weight $[\mathrm{kg}]$ & $163,8 \pm 7,9$ & $80.8 \pm 16.4$ \\
Height $[\mathrm{cm}]$ & $29.2 \pm 5.2$ & $167.3 \pm 11.3$ \\
BMI & 66.6 & $28.7 \pm 3.9$ \\
Hypertension \% & 9.1 & 80 \\
Diabetes mellitus $\% *$ & 8.33 & 30 \\
Smokers\%* & $182.0 \pm 36.6$ & 20 \\
TC $[\mathrm{mg} / \mathrm{ml}]$ & $49.6 \pm 8.3$ & $199.0 \pm 63.2$ \\
HDL $[\mathrm{mg} / \mathrm{m}] 1$ & $108.0 \pm 32.2$ & $47.8 \pm 16.8$ \\
LDL $[\mathrm{mg} / \mathrm{m}] 1$ & $125.2 \pm 44.4$ & $120.2 \pm 54.4$ \\
TG $[\mathrm{mg} / \mathrm{m}] 1$ & $6.3 \pm 1.5$ & $153.5 \pm 61.8$ \\
IGF-1/BMI kg/m^2 & $176.7 \pm 34.2$ & $7.6 \pm 2.8$ \\
IGF-1 [ng/ml]* & $2052.0 \pm 488.3$ & $215.0 \pm 71.3$ \\
IGFBP3 [ng/ml] & & $2115.8 \pm 738.4$ \\
\hline
\end{tabular}

\begin{tabular}{lll}
\hline & $\begin{array}{l}\text { Coronary arteries without } \\
\text { narrowing lesions in coronarography, } \\
\text { 0 points in gensini scale, } \\
\text { mean value } \pm \text { SD } \\
(\mathrm{N} \mathrm{18)}\end{array}$ & $\begin{array}{l}\text { Advanced arteriosclerosis } \\
\text { reflected by high gensini } \\
\text { score, mean value } \pm \text { SD (N 9) }\end{array}$ \\
\hline Age [years] & $56.8 \pm 10.0$ & \\
Weight [kg] & $77.2 \pm 17.4$ & $64.2 \pm 10.6$ \\
Height [cm] & $164.2 \pm 8.4$ & $83.8 \pm 10.8$ \\
BMI & $28.4 \pm 5.2$ & $170.2 \pm 9.0$ \\
Hypertension \% & 64.7 & $29.0 \pm 3.3$ \\
Diabetes mellitus\%* & 12.5 & 77.8 \\
Smokers\%* & 23.5 & 33.3 \\
TC [mg/ml] & $192.9 \pm 38.6$ & 11.1 \\
HDL [mg/m]1 * & $50.3 \pm 10.5$ & $184.4 \pm 73.0$ \\
LDL [mg/m]1 & $116.5 \pm 30.8$ & $41.4 \pm 7.7$ \\
TG [mg/m]1 & $132.3 \pm 48.4$ & $111.1 \pm 59.7$ \\
IGF-1/BMI kg/m^2 & $6.5 \pm 1.7$ & $159.4 \pm 59.6$ \\
IGF-1 [ng/ml]* & $181.0 \pm 37.8$ & $8,0 \pm 2.3$ \\
IGFBP3 [ng/ml] & $2377.2 \pm 674.0$ & $231.4 \pm 59.3$ \\
\hline
\end{tabular}

score $231.4 \pm 59.3$ versus $181.0 \pm 37.8 \mathrm{ng} / \mathrm{ml} p=0.01$ ). Significant but weak correlations were found between IGF-1 and total cholesterol $(\mathrm{R}=0.238, p=0.02)$, LDL cholesterol $(\mathrm{R}=0.204, p=0.04)$ and $\mathrm{TG}(\mathrm{R}=0.250, p=0.01)$, but not with other lipoproteins. We observed no significant relation between IGF-1, IGFBP's, and history of MI ( $p=$ / $0.24,0.77 /$ respectively), CAD familial history $(p=/ 0.1,0.12 /$ respectively), hypertension( $p=/ 0.74,0.95 /$ respectively), or diabetes type $2(p=/ 0.58,0.15 /$ respectively).

\subsection{Results of Genotyping}

We observed different single DNA strand migration of P1 promoter of IGF-1 gene/divided into 4 fragments/in 123 samples (in a group of 101 patients in total). In 45 patients we found 5 polymorphism, previously described in the NCBI data. We found RS35767 polymorphism at $-1245 \mathrm{nt}$, (29 subjects of genotype $\mathrm{C} / \mathrm{T}$ and 1 of $\mathrm{T} / \mathrm{T}$ ), which constituted 28.7 and $0.99 \%$ of all examined patients (C/T was 
Table 4 Frequency of various genotypes

\begin{tabular}{clllll}
\hline & $\begin{array}{l}\text { Polymorphism } \\
\text { RS 35767 (genotype } \\
\text { and number of patients) }\end{array}$ & $\begin{array}{l}\text { Polymorphism } \\
\text { RS 11829693 } \\
\text { (genotype and } \\
\text { number of patients) }\end{array}$ & $\begin{array}{l}\text { Polymorphism } \\
\text { RS 5742612 } \\
\text { (genotype and } \\
\text { number of patients) }\end{array}$ & $\begin{array}{l}\text { Polymorphism } \\
\text { RS 2288377 } \\
\text { (genotype and } \\
\text { number of patients) }\end{array}$ & Various polymorphisms \\
\hline Female & $\begin{array}{l}\text { Genotype C/T-14 } \\
\text { genotype T/T-1 }\end{array}$ & Genotype A/A-2 & Genotype C/T-4 & Genotype A/T-1 & $\begin{array}{c}\text { Two subjects of (A,B)*, } \\
\text { one subject of C* }\end{array}$ \\
Male & $\begin{array}{l}\text { Genotype C/T-15 } \\
\% \mathrm{~F}\end{array}$ & 0 & Genotype C/T-3 & Genotype A/T-1 & $\begin{array}{c}\text { One subject of (B) } \\
\% \mathrm{M}\end{array}$ \\
\hline 26.3 & 5.56 & 9.09 & 1.75 & 5.17 \\
\hline
\end{tabular}

A* (genotype C/T of RS 35767, genotype A/A of RS 11829693, genotype C/T of RS 5742612), B* (genotype C/T of RS 35767, genotype C/T of RS 5742612, genotype A/T of RS 2288377, C* (genotype T/T of RS 35767, genotype C/T of RS 5742612)

found in 14/31.82\%/of all examined women, in one subject homozygote of $\mathrm{T} / \mathrm{T}$ was observed). In 15 men heterozygotes of $\mathrm{C} / \mathrm{T}$ were in evidence $(26.32 \%$ of all examined men). The rest were probably homozygotes of $\mathrm{C} / \mathrm{C}$. We found 2 cases of homozygote A/A for polymorphism RS11829693 at $-933 n t$, i.e. in $1.98 \%$ of the entire examined population. RS5742612 polymorphism, genotype C/T (at $-540 \mathrm{nt}$ of P1 promoter) was observed in seven patients. The rest were homozygotes T/T. In addition we found two cases of weak type of polymorphism RS2288377 (heterozygote of genotype $\mathrm{A} / \mathrm{T}$ at $-438 \mathrm{nt}$ of $\mathrm{P} 1$ promoter), i.e. in $1.98 \%$ of all subjects. The rest were probably homozygotes of $\mathrm{T} / \mathrm{T}$. All subjects were homogenus with regard to genotype A/A of polymorphism RS17879774 in $-97 \mathrm{nt}$ of promoter region $\mathrm{P} 1$ for $I G F-1$ gene. A coexistence of various genotypes are show in Table 4 .

We observed significant differences in serum high densinity lipoprotein (HDL) in patients with the presence of genotype $\mathrm{C} / \mathrm{T}$ and $\mathrm{T} / \mathrm{T}$, compared to those with $\mathrm{C} / \mathrm{C}$ genotype for polymorphism RS35767 (43.7 \pm 16 vs. $50.6 \pm 11.3 \mathrm{mg} / \mathrm{dl} p=0.042$ ),

We did not observe any significant association between observed SNP's with the degree of coronary atherosclerosis defined as the number of culprit lesions or the Gensini scale score.

We found no structural polymorphism in gene for IGF-1 receptor in its extracellular domain (exon 2-4) and internal domain (exon 16-21).

\section{Discussion}

There is increasing evidence for the role of IGF-1 in vascular pathologies, including arteriosclerosis, but the function of this protein is still unclear [12].

We noticed significantly elevated circulating levels of IGF-1 in patients with significant obstructive lesions in all three coronary arteries in contrast to those without changes.
(This information was obtained from the analysis of coronary angiographic images, and later confirmed by the analysis of Gensini scale score). Even though that IGF-1 levels are age dependent [7], our experimental group with high Gensini scores were older and with " 3 vessel disease" were significantly older than control patients without narrowing lesions in coronary arteries. There were no other significant differences between studied groups with regard to parameters which may influence IGF-1 biosynthesis except for higher occurrence of diabetes mellitus (DM) in group with advanced coronary arteriosclerosis. (Tables 2,3). Due to the fact that DM was related to decreased levels of IGF-1 [6], it does not interfere with results of our analysis.

The major goal of our study was to find a possible molecular cause of serum IGF-1 level differences in previously described group of patients. We found 5 polymorphisms in $\mathrm{P} 1$ promoter region of IGF-1 gene, previously described in the NCBI database. We additionally used TRANSFAC system to evaluate possible modulations in transcriptional factors attached to the observed $\mathrm{P} 1$ promoter sequence. Having analysed data with TRANSFAC system, we may assume that the disturbed attachment of such factors as (C/EBP(CCAAT enhancer binding protein) Hoxa3,Sp1 (serine protease inhibitor) or GATA-1, (GATA nucleotide sequence) may have an impact on IGF-1 protein synthesis, but we did not observed any significant correlation between promoter P1 polymorphism and serum IGF-1 levels. To be precise, higher levels of IGF-1 with genotype A/A of polymorphism RS11829693, and lower levels with genotype T/T for polymorphism RS35767 were observed, but the low number of subjects precluded valid statistical analysis. Besides, these genotypes occur very seldom in a population, which may lead to a conjecture that their meaning is marginal.

Genotype C/T for RS5742612 occurred with significantly higher frequency in the group of patients with stroke history (Yates $\chi^{2} p=0.046$, Test $\chi^{2} p=0.03$, Fisher exact, one-tailed $p=0.041$, Fisher two-tailed $p=0.041$ ). 
Additionally, the region between -1115 to -784 nt (of P1 promoter of $I G F-1$ gene) underwent a precise analysis, due to a different number of dinucloetide GC repeats (alleles Bp192/194-38/42nt in our study). We found higher IGF-1 levels in "variant carriers" (in opposition to Yazdanapah [16]) [3], without any effect on the progression of coronary atherosclerosis, what was confirmed by precise GC estimation [4].

"Variant carrier" is an artificial term introduced by Yazdanapah which describes not a simple genotype but a few genotypes of GC repeats in region between -1115 to -784 nt of P1 promoter [16]. Therefore it is difficult to establish their real frequency in population and in our opinion it is even hard to speculate about its meaning.

The frequency of other alleles for various genotypes found in our study are comparable to those described in NCBI database, however, our study had the advantage collecting data from a large group of subjects. In relevant literature, the IGF-1 gene is described as constitutive, therefore we did not analyze the sequence of gene. Nevertheless, we decided to analyze the IGF-1 receptor gene, responsible for the IGF-1 binding. The analysis have not shown molecular disturbances in the structure of its external (exon 2-4) and internal (exon 16-21) domains. This lead to the conclusion that the increased IGF-1 in advanced angina patients in our study was probably independent from disturbances in sequences of IGF-1 gene or its promoter $\mathrm{P} 1$ as well as $\mathrm{IGF}-1$ receptor gene. We may only presume that the one of the possible explanation of increased IGF-1 serum levels in examined subjects could be the condition of advanced coronary arteriosclerosis.

We surmise that higher levels of serum IGF-1 could be explained by possible cardioprotective properties of IGF-1. The escalation of clinical symptoms of angina in the studied group occurred probably several weeks before coronary angiography. As discussed in our recent data [3], it was enough to develop circulating IGF-1 adaptation, in order to protect lesions (those patients have negative MI history) from rupture. It is possible that the elevation of IGF-1, stimulated by persistent myocardial ischemia, could be a systemic part of heart preconditioning. In case of MI occurrence it will probably serve as a means of protection against heart failure. The confirmation of this hypothesis can be found in the clinical followup of MI subjects in Friberg study [7]. Poor patients' prognoses in this trial were shown to be significantly associated with heart failure occurring after infarction, in consequence of decrease in systemic IGF-1 levels [7].

There are several limitations of our study. First, we had not performed echocardiography.

Second we excluded patients with diagnosed clinical symptoms of peripheral arteriosclerosis due to a fact that any peripheral arteriosclerosis may influence the action of
IGF-1 [11]. We did not perform the peripheral doppler duplex imaging, so it was therefore impossible to exclude all cases of peripheral arteriosclerosis. Thirdly, coronary angiography used in our study for quantification of coronary arteriosclerosis may also have its limitations (e.g. do not permit for evaluation of the 'in-wall' process). The final limitation of our protocol is the fact of $\mathrm{GH}$ (strong IGF-1 stimulator) estimation only in 38 patients. GH levels would probably verify whether IGF-1 elevation is caused only by $\mathrm{P} 1$ promoter or receptor gene irregularity. With a positive configuration of the latter, investigation of possible clinical importance of the molecular mechanism of elevation in circulating IGF-1 levels and its association with lipid metabolism in patients with advanced stable angina should be established.

\section{Conclusion}

On the basis of the study protocol we conclude that effect of increased IGF-1 serum level was probably independent from $I G F-1$ gene or its regulating and receptor (extra and intracellular domain) sequence structure.

Acknowledgments The study was supported by 2006 Polish Cardiac Society research grant founded by Servier Poland. Posters presentation based on the results of the study were presented at ESC 2007, 2009, ACC 2009 and Europrevent 2009. Special thanks for Simon Nowak for contribution in text edits.

Conflict of Interest The study was free of any conflict of interest.

Open Access This article is distributed under the terms of the Creative Commons Attribution Noncommercial License which permits any noncommercial use, distribution, and reproduction in any medium, provided the original author(s) and source are credited.

\section{References}

1. Bayes-Genis A, Conover C, Schwartz R (2000) Circ Res 86:125-130

2. Bolster D, Jefferson L, Kim S (2004) Proc Nutr Soc 63:351-356

3. Burchardt P, Gozdzicka-Jozefiak A, Nowak W, Link R, Grotowski T, Wisniecka A, Siminiak T (2009) Heart Vessels 24(4):254-259

4. Burchardt P, Nowak W, Zurawski J, Gozdzicka-Jozefiak A, Siminiak T (2010) Protein J 29(7):524-529

5. Che W, Lerner-Marmarosh N, Huang Q, Osawa M, Ohta S, Yoshizumi M, Glassman M, Lee JD, Yan C, Berk BC, Abe J (2002) Circ Res 90:1222-1230

6. Delafontaine P, Song Y-H, Li Y (2004) Arterioscler Thromb Vasc Biol 24:435-444

7. Friberg L, Werner S, Eggertsen G, Ahnve S (2000) Eur Heart J 21:1547-1554

8. Frystyk J, Ledet T, Moller N, Flyvbjerg A, Orskov H (2002) Circulation 106:893-895 
9. Grant MB, Wargovich TJ, Ellis EA, Tarnuzzer R, Caballero S, Estes K, Rossig M, Spoerri PE, Pepine C (1996) Regul Pept 67:137-144

10. Janssen JA, Stolk RP, Pols HA, Grobbee DE, Lamberts SW (1998) Arterioscler Thromb Vasc Biol 18:277-282

11. Juul A, Scheike T, Davidsen M, Gyllenborg J, Jorgensen $T$ (2002) Circulation 106:939-944

12. Kaplan RC, Strickler HD, Rohan TE, Muzumdar R, Brown DL (2005) Cardiology in Review 13:35-39
13. Okura Y, Brink M, Zahid AA, Anwar A, Delafontaine P (2001) J Mol Cell Cardiol 33:1777-1789

14. Patel VA, Zhang QJ, Siddle K, Soos MA, Goddard M, Weissberg PL, Bennett MR (2001) Circ Res 88:895-902

15. Shimasaki S, Ling N (1991) Prog Growth Factor Res 3(4):243-266

16. Yazdanpanah M, Rietveld I, Janssen JA, Njajou OT, Hofman A, Stijnen T, Pols HA, Lamberts SW, Witteman JC, van Duijn CM (2006) Am J Cardiol 97:1274-1276 